\title{
„Firma vydělává, děti se učí, žena je hodná a já jsem šfastný." Představy dětí o budoucím životě
}

\author{
"My Business is Doing Well, My Children are Good at School, \\ My Wife is Kind and I am Happy": Children's Views of their \\ Future Life
}

Lenka Slepičková

\begin{abstract}
This article focuses on the ways in which children, specifically children aged 8-10 and 12-13 years, project their future lives, how they present them, and their aspirations, expectations and wishes for the future. The analysis is based on different sources of qualitative data (drawings, essays, creating timelines, etc.) gathered within a wider research project conducted at two Moravian primary schools. The data show how children perceive social standards and values relating to different periods of life, and how they perceive different expectations in relation to gender. Children formulate their own life plans and ideas in a series of stages, beginning with a preparatory stage associated with the educational system and the acquisition of competencies, continuing to the phase of finding a stable partnership and building families and ending in old age which is described as a life phase marked by a loss of energy, health and competencies. While girls describe their future life plans in terms of an intensive and successful involvement in various life spheres - professional as well as private - boys envision their future as a life of single beings pursuing their own dreams and hobbies, surrounded by their families, but highly individualized.
\end{abstract}

KEY WORDS childhood, future life, agency, gender, age norms

\section{Úvod}

Zkoumání dětí v rámci tzv. nového paradigmatu sociologie dětství vychází z předpokladu, že požadavek reflexivní práce na vlastní biografii, který je spojován s životem v době pozdní modernity, se vztahuje také na děti (Moxnes 2003). Dítě je v rámci tohoto př́stupu zkoumáno jako někdo, kdo je schopen konstruovat vlastní identitu, aktivně sjednocovat či selektovat různorodé socializační vlivy a vyvíjet si vlastní perspektivu na nejrůznější fenomény, která se může významně lišit od perspektivy dospělých (Coleman, Ganong a Fine 2004; Berg 2003). Komplexnost dětské životní zkušenosti, která je spojována s proměnlivostí rodinných usporádání a různorodostí socializačních vlivů, a způsob, jakým se odráží v dětské zkušenosti, se

Sociálni studia. Katedra sociologie FSS MU, 2/2012. S. 83-102. ISSN 1214-813X.

1 Práce na výzkumu a tomto textu byla podpořena Grantovou agenturou ČR, projekt „Rodina pohledem dětí“, GAP404/11/1033. 
stává samostatným výzkumným tématem. Tento náhled na dětství a dítě zároveň generuje specifické metodologické př́stupy, které staví dítě jako aktéra do centra svého zájmu (někdy z něj činí i výzkumníka nebo spoluvýzkumníka) a soustředí se na takové metody výzkumu, které respektují dětskou zkušenost a kompetence.

V našem výzkumu se zabýváme právě procesem dětského konstruování identity, a to konkrétně na př́kladu představ dětí o vlastní budoucnosti. Schopnost představit si vlastní budoucnost je klíčovou kompetencí, která se spojuje se schopností být členem společnosti a směrovat svou životní dráhu (Bonny a Bertsen 2012). Budování identity se odehrává v kontextu společenských norem a hodnot a socializačních vlivů (Greene a Hogan 2005). Ptáme se, jakým způsobem děti - konkrétně děti navštěvující 3. a 7. tř́ídy základní školy (tedy děti ve věku 8-10 a 12-13 let) - preméššlejí o svých budoucích životních drahách, jak je prezentují, na co v jednotlivých oblastech svého života aspirují. Zajímá nás také, jak se tyto aspirace liší u dívek a chlapcủ, a zda v nich můžeme najít odrazy individualizačních tendencí, připisovaných životním drahám v pozdní modernitě, či konkrétních socializačních vlivů.

Vycházíme přitom z různých zdrojů dat kvalitativní povahy (z obrázků a písemných prací, z kreslení časových os atd.), která byla získána $\mathrm{v}$ rámci širšího výzkumného projektu, probíhajícího v prostředí dvou základních škol. ${ }^{2}$ Hlavním tématem výzkumu bylo dětské nahlížení na rodinu a blízké vztahy. Následující text je tedy prezentací dílčí části tohoto projektu, zaměřenou právě na představy dětí o vlastní budoucnosti.

Projekce dětí týkající se vlastní budoucnosti jsou vděčným objektem výzkumu, a to jak $\mathrm{z}$ hlediska vývojové psychologie (např́klad Bohn a Berntsen 2012), tak - např́klad v souvislosti se vzdělanostními aspiracemi - z hlediska sociologie (Pimlott-Wilson 2011). V českém prostředí byly děti a mladí lidé zkoumáni prostréednictvím kvantitativních metod např́ílad ve vztahu k představám o budoucím partnerském a rodinném životě (Fialová a kol. 1998, Katrňák a kol. 2010). Děti a teenageři jsou v rámci těchto výzkumů - v době následující po radikální proměně demografického chování české populace - považováni za generaci, od které se očekává změna a nová životní perspektiva, nebot' byla socializována, na rozdíl od generace jejich rodičů, již $\mathrm{v}$ podmínkách nového demografického, ale i politického a hodnotového režimu. $V$ jejich názorech a představách o budoucnosti se tak hledají odpovědi na otázky, zda změna demografického chování (která se nejvýrazněji projevuje a také tematizuje jako prudký pokles porodnosti, sňatečnosti a odkládání období zakládání rodiny), bude trvalým jevem a známkou nastoupení české společnosti na západoevropský demografický (i hodnotový) režim, nebo dočasnou reakcí na anomickou situaci, která provázela transformaci české společnosti, a po které bude následovat obrat k chování odrážejícímu tradiční a konzervativní hodnoty české populace (viz Rabušic 2001, Rychtaříková 2000).

Genderovou perspektivu a kvalitativní metody výzkumu uplatnily ve svých výzkumech Lucie Jarkovská (2010) a Irena Smetáčková (2010), které se pomocí projektivních technik zabývaly mj. způsoby, jakými dívky a chlapci konstruují svou životní dráhu. Dívčí a chlapecké aspirace ve sfére vzdělání a způsoby jejich socializace do profesních drah byly tématem výzkumu autorského kolektivu Jarkovská, Lišková a Šmídová (2010). Rozsáhlou

2 Na tomto projektu a sběru dat jsme pracovaly jako tým ve složení Michaela Kvapilová Bartošová, Kateřina Dvořáková, Beatrice Chromková Manea a Lenka Slepičková. 
kvantitativní a částečně kvalitativní sondou do životní situace, hodnot, vztahů a aspirací dětí ve věku 6-15 let byl výzkum Národního institutu dětí, mládeže a rodiny (Bocan a kol. 2012).

Náš výzkum tak chce přispět $\mathrm{k}$ výše zmíněným poznatkům $\mathrm{s}$ využitím výhod, které mu dala kombinace různých metod sběru dat $\mathrm{v}$ rámci jednoho výzkumného projektu, zároveň s reflexí omezení, které pro něj znamenalo prostředí výzkumu - prostředí školní tř́dy. Během zpracování dat se ukázala být velmi významnou osou, která ovlivňuje dětskou perspektivu vlastní budoucnosti, osa genderová, které se proto nejvíce věnuje také následující text. Ten je uvozen popisem výzkumné metodologie a shrnutím toho, jak děti obecně konstruují své životní dráhy. Následuje část věnovaná genderovým aspektům projekce vlastní budoucnosti.

\section{Výzkum}

Zájem o dětské aktérství je jádrem nového paradigmatu pro studium dětství, které se v sociálních vědách formuje od 70 . let minulého století. Tato perspektiva zdůrazňuje schopnost dětí a mladých lidí aktivně utvářet svůj život, vyvíjet si specifické vidění sociálního světa, a také být aktivním hráčem na poli změn, které se týkají celé společnosti (James 1994, Greene a Hogan 2005). Kromě formulování nových témat a výzkumných otázek týkajících se dětí a dětství vyvolala nová sociologie dětství radikální proměny $\mathrm{v}$ metodologických př́stupech ke zkoumání dětí, které souvisejí s novým viděním dětí jako kompetentních informantů o vlastním životě.

Tento text vychází z výzkumu, jehož hlavním tématem byla dětská perspektiva týkající se rodiny a blízkých osob. Sběr dat probíhal na dvou běžných základních školách (jedna z nich se nachází blízko centra moravské metropole, druhá v malém městě pobliž) a u dvou věkových skupin dětí - ve 3 . a 7. třídách. Kontakt s těmito školami byl navázán na základě sociálních sítí výzkumnic - hledaly jsme školy, které by $\mathrm{k}$ výzkumu byly vstřícné a umožnily nám opakovaně se setkávat s dětmi v době školního vyučování. Školy, v nichž výzkum probíhal, jsou „běžnými“ školami v mnoha ohledech tohoto slova - nejsou umístěny v prominentních ani problematických lokalitách města a obce, nabízejí standardní vzdělávací program (ani jedna ze škol není nějakým způsobem specializovaná) a skladba žáků i jejich socioekonomické zázemí jsou velmi různorodé.

Výzkum se odehrál v rámci několika (6 až 7) návštěv školy v průběhu vyučovacích hodin (nejčastěji hodin výtvarné nebo občanské výchovy, př́ípadně v hodině češtiny), předcházelo mu vysvětlení jeho tématu, cíle a průběhu dětem a vyučujícím a žádost o souhlas $\mathrm{s}$ výzkumem od rodičủ dětí a od dětí samotných. Výzkumu, nebo alespoň některých jeho částí, se zúčastnilo celkem 84 dětí, 43 chlapců a 41 dívek. ${ }^{3}$ Výzkumné aktivity probíhaly

Během výzkumu jsme různými způsoby - s pomocí obrázků vlastní rodiny, rodokmenů či v individuálních rozhovorech, získaly informace o rodinném zázemí 71 účastníků výzkumu. Z nich 45 žilo $\mathrm{v}$ nukleární rodině, $15 \mathrm{z}$ nich $\mathrm{v}$ rodině rozšířené a jen $11 \mathrm{z}$ nich v rodině jiného typu, složené po rozvodu či v rodinách s jedním rodičem. Informace o vzdělání nebo povolání rodičů jsme nezjištovaly systematicky a získaly jsme je u menšího počtu dětí - téma návaznosti projektovaných životních drah na rodinnou socializaci, jakkoli zajímavé, tak zůstává mimo záběr našeho výzkumu. 
někdy za přítomnosti učitelky, někdy jen za přítomnosti výzkumnic samotných, záviselo to na zvážení samotných vyučujících. ${ }^{4}$

$\mathrm{V}$ rámci výzkumu byla použita řada technik sběru dat, a to jak techniky využívané běžně i ve výzkumech s dospělými (focus group, individuální rozhovory), tak techniky sběru dat, které jsou blízké dětským dovednostem a obvyklým činnostem (kreslení, hry, diagramy); některé z nich jsme zkonstruovaly konkrétně pro tento výzkum. Následující analýza se tematicky soustředí na představy dětí o vlastní budoucnosti, a vychází především ze dvou technik sběru dat - ze zobrazování událostí dětmi na časové ose a popisů a obrázků týkajících se prèstav o vlastní budoucnosti. Způsoby sběru dat jsou podrobněji uvedeny v jednotlivých částech textu.

\section{Představy dětí o vlastní životní dráze}

Mladší i starší děti jsme požádaly, aby na časovou dráhu, kterou si samy na velký formát papíru nakreslily a časově vymezily, umístily události podle toho, jak očekávají, že se v jejich životě stanou. Výběr a pojmenování etap a událostí jsme částečně nechali na dětech, nabídli jsme jim však seznam asi čtyřiceti událostí různého typu (uspořádaných náhodně) pro př́ipad, že by neměly pro úkol dost nápadů. $Z$ těchto předem definovaných událostí se nakonec $\mathrm{v}$ časových osách objevily hlavně ty, které lze považovat za nejdůležitějš́ tranzice v životní dráze (svatba, narození dětí, ukončení školy, odchod do důchodu), zatímco jiné události (jazykový kurz, založení hudební skupiny), které jsme definovaly v rámci snahy nabídnout širokou škálu možností a sfér činností, se ve vytvořených drahách objevily jen sporadicky. Děti oproti tomu nabízely celou řadu etap a událostí, které definovaly samostatně. Z životních drah dětí jsme pak vytvořily souhrnné životní dráhy (pro starší a mladší děti, pro dívky a chlapce) tak, že jsme jednotlivé dětmi zaznamenané a pojmenované události vynesly souhrnně na osy vymezující věk, v němž se mají stát. Bylo tak možné vidět vzorce a pravidelnosti, které se $\mathrm{v}$ projektovaných životních drahách vynořily.

Děti své plány koncentrovaly do nižšího věku a nejbližšího časového období - většina událostí je tak datována od současného věku zhruba do třiceti-čtyřiceti let, zatímco popis událostí ve vyšším věku je chudši (nejvíce popsaných událostí se v pozdějším věku soustředí kolem odchodu z pracovního života a narození vnoučat) - konec života či smrt však označily na časové ose téměř všechny děti. $\mathrm{V}$ životních drahách dětí jsou jasně patrné jednotlivé

4 Jsme si vědomy toho, že přítomnost učitelské postavy ve třídě pro děti zprostředkovávala školní autoritu a generovala náhled na výzkumné aktivity jako na školní práci, kterou je třeba udělat především správně a v souladu s očekáváním. Nenašly jsme však způsob, jakým v komunikaci s učitelkami naši roli a vzájemná očekávání lépe (se zachováním zdvořilých vztahů a s oceněním jejich vstřícnosti k našemu výzkumu) vymezit. Zároveň nás přítomnost učitelky ve třídě zbavovala přimé zodpovědnosti za děti a mohly jsme se soustředit na výzkumnou práci a kontakt s dětmi, aniž bychom musely kontrolovat jejich odchody ze třídy atd. Snažily jsme se také vliv přítomnosti učitelky zmírnit důrazem na samostatné a svobodné vyjádření se v rámci činností, probíhajících během výzkumu, které bylo někdy podpořeno jejich samotným formátem (prováděly jsme např́iklad skupinové rozhovory), uspořádáním tř́idy, která byla během výzkumu přebudovávaná tak, aby děti seděly po skupinkách atd. 
etapy - věkové úseky, do nichž děti umístovaly převážně jeden typ událostí. Lze je rozlišit na etapu vzdělávací, do níž umíst'ují události týkající se ukončení školy a přechodu na další vzdělanostní stupeň, včetně získání řidičského průkazu, které jako událost na životní dráze často zmínili jak dívky, tak chlapci. Tato etapa je obvykle ohraničena věkem kolem 25 let ukončením vysoké školy.

Další etapou, která následuje po etapě vzdělávací, je etapa partnerství, sňatků a zakládání rodiny - dívky a chlapci se jí věnovali zhruba ve stejné mír̃e a plánovali podobný počet dětí. Etapy v životní dráze dívek, a to jak mladších, tak starších, jsou ale ve srovnání s životními dráhami chlapců jasněji ohraničené a jednotlivé události jsou koncentrované do nižšího věku - zdá se, že dívky předpokládají, že nejvíce událostí se v jejich životě stane zhruba do 30 let, zatímco chlapci umístovali události různého typu častěji i do vyššího věku. Chlapci také do časové osy ve srovnání s dívkami častěji zapisovali události týkající se koníčků (například v podobě zážitků ze shlédnutí významného zápasu ve fotbale či vlastního sportovního úspěchu). Během vyplňování časových os jsme procházely mezi dětmi a postřehly jsme živou diskusi starších dívek o tom, zda mají do časových os zanést také první sex. Vybídly jsme je k tomu, at tak klidně učiní a na časových osách starších dětí se tak několikrát objevila i tato událost, a to u několika dívek v sedmé tř́ídě, spojena s věkem 15-16 let, a u jednoho chlapce ze stejné trrídy ve věku 21 let. $^{5}$

Kromě vzdělávacích a rodinných plánů děti $\mathrm{v}$ rámci projektovaných životních drah zmiňovaly také své profesní a konzumní aspirace - ty první často začínají brigádami v blízkém věku, pokračují nástupem do práce a změnami v pracovním životě a vrcholí odchody do důchodu. Dívky očekávají přerušení své pracovní dráhy odchody na mateřské dovolené, po kterých následuje opětovný návrat do práce. Konzumní aspirace mají podobu nákupů domů a bytů, aut a motorek - oba typy událostí, profesní i konzumní, zmiňovaly mnohem častěji chlapci než dívky.

Zajímalo nás, zda se v podobě projektovaných životních drah odrazí flexibilita a proměnlivost životní dráhy. Předpokládá se, že životní dráhy přestávají být v pozdně moderní společnosti rigidní a nutně chronologické, pro jednotlivé životní etapy neplatí fixní definice a jednotlivé tranzice se z povinných aspektů sociálního života staly aspekty volitelnými (Hunt 2005). Životní dráhy projektované dětmi však mají podobu lineárních drah, které popisují normativní životní biografii, začínající př́ípravou na profesní život ve vzdělávacím systému, kolem které se koncentrovalo nejvíce zmíněných událostí, pokračující skrze partnerství, sňatky a zakládání rodin a uzavírající se v důchodovém věku tradicemi spojenými s odchodem z pracovního života a prarodičovstvím. Děti ve svých životních osách nepočítaly př́liš často s událostmi, jako je změna partnera/partnerky či změna kariéry nebo

5 Patnáct let věku je v České republice legální hranicí pro pohlavní styk. Ve výzkumu Katrňáka a kol. (2010) však 15,8 \% chlapců a 10,4 \% dívek uvedlo, že první pohlavní styk uskutečnili již před patnáctými narozeninami, ve věkové skupině $15-17$ let má za sebou první sex $66 \%$ dívek a $52 \%$ chlapcủ. $Z$ těchto dat i z popisu výzkumné situace je zrejmé, že téma prvního sexu je ve věku dětí našeho výzkumu tématem vysoce aktuálním. Podle vyjádření učitelky jedné ze škol, na které probíhal výzkum, však výuka témat týkajících se sexuálního a partnerského života probíhá především v 8. trí́dě. 
vzdělání ve vyšším věku, ani s událostmi seberealizačního typu, jako je studium v cizině, bydlení s přáteli či cestování - jsou to události, které, jak sociologové předpokládají, vytlačují z životních drah mladých lidí aspirace na stabilní partnerství a rodičovství, př́ípadně je výrazně zpožd'ují (Rabušic 2001). Zároveň do plánů mladých lidí pronikají nikoli jen jako zcela legitimní, ale očekávaná životní etapa (Kvapilová Bartošová 2012). I v rámci tradičně konstruovaných životních drah, které $\mathrm{v}$ dětských zpracováních časových os převládaly, však můžeme vnímat rozdíly v pojetí, a to především mezi chlapci a dívkami: týká se to rigidnějších věkových hranic, které projektovaly dívky, stejně jako výběru událostí - zatímco $\mathrm{v}$ těch týkajících se vzdělání a rodinných ambicí se dívky ani chlapci nelišily, chlapci mnohem častěji zmiňovali události týkající se realizace ve veřejné sféře (vydělávání peněz, povýšení v práci) a ve sféře vlastních koníčkủ a aktivit, stejně jako nákupy předmětu (nejčastěji auto, motorka) a nemovitostí (byt a dům). Rozdílnosti životních aspirací dívek a chlapců tak, jak se ukázala $\mathrm{v}$ rámci tohoto výzkumu, bude podrobněji věnovaná druhá část textu.

Časové osy se výběrem důležitých životních událostí př́liš nelišily u dětí mladšího a staršího věku - některé děti mladšího věku ale ve své ose zmiňovaly častěji události uvozené slovem „už“, kterými zdůrazňovaly očekávání nově nabytých kompetencí souvisejících $\mathrm{s}$ věkem či zkušenostmi. Podobným příkladem je životní dráha jedné z mladších dívek, která vyjadřuje předpoklad samostatnosti a větší „,chytrosti“ ve vy̌̌ším věku, jako specifickou etapu v životním cyklu zmiňuje „týnejdžerství“:

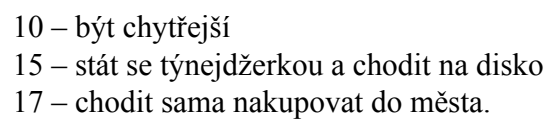

Událostí spojených s vyšším věkem se jak na časové ose, tak v popisech budoucnosti neobjevovalo př́liš mnoho - je to logické, stáŕí je etapou, která je dětem nejvíce vzdálena a je pro ně ve vztahu k vlastní osobě nejvíce abstraktní. Na druhé straně jim však je zprostředkována skrze vztahy a kontakty s př́ibuznými ve vyšším věku, především prarodiči. Jak ukázaly jiné techniky použité ve výzkumu a zaměřené na blízké vztahy dětí, prarodiče pro děti figurují na prvních místech ve vztazích týkajících se podpory či svěrování se vedle rodičů, sourozenců a kamarádů.

Události spojované s vyšším věkem (odchod do důchodu, zdravotní potíže, prarodičovství) děti umístovaly do širokého věkového rozpětí, cca od 45 let. Klíčovými tranzicemi, které děti spojují s věkem cca od padesáti let výše, jsou tranzice dvojího druhu - tranzice související s rodinným životem (jedná se především o svatbu potomků a narození vnoučat, př́ípadně pravnoučat) a tranzice související s odchodem z pracovní sféry. Mnohé děti také zmínily úmrtí rodičů jako jednu z událostí v životní dráze - rodiče byli u několika dětí př́tomni i na obrázcích o budoucnosti. Mezi dalšími událostmi, které děti spojovaly s vyšším věkem, je stěhování - do domova důchodců, z domu do bytu nebo do horské oblasti - až na poslední př́ípad se tedy jedná o snížení statusu bydlení v souvislosti s důchodovým věkem. Některé děti namísto konkrétních událostí na časových osách ohraničovaly životní etapy, a to napríklad „stáríi“, datované od 60 let výše, nebo „děti v pubertě“, také od 60 let výše. 
S vyšším věkem děti spojují zdravotní obtíže a úbytek psychických a fyzických sil, které zobrazují někdy skrze konkrétní zdravotní pomůcky a diagnózy (45 - mám berle a už je nechci nosit, 91 - budu sotva stát na nohou, 45 - už mám brýle a bolí mě záda a nikdo ode mě nechce pomoct, 70 - už jsem na vozíčku a mívám infarkty). Událostí, kterou dva chlapci shodně (patrně ve spolupráci) umístili do věku 90 let, je „nová berle“ jako alternativa k ostatním událostem a aktivitám, plánovaným $\mathrm{v}$ nižším věku. Tato událost naplnila $\mathrm{v}$ obou př́ípadech prázdný úsek časové osy ve vyšším věku - a je událostí kombinující prvek pozitivní (nákup něčeho nového) s tím, co je stáŕí stereotypně připsáno (koncentrace života na úpadek fyzických sil a snahu jej nějak kompenzovat).

Stáří děti také spojují s blížící se smrtí ( 90 - jdu na pohřeb kamarádům, 100 - už si budu říkat, kdy konečně umřu). Téma zhoršujícího se zdraví a smrti se objevilo i v jiné technice sběru dat, kterou jsme ve výzkumu také použily, a to v popisech toho, jak si děti představují ideální prarodiče - zde některé děti zmiňovaly „nesmrtelný“, „zdravý'“ a „nebere prášky“ mezi vlastnostmi ideálních prarodičů. Objevilo se zde také téma „ubrblanosti“, „tvrdohlavosti“" nebo „nadávání“, stejně jako „nakupování ve slevách“ coby atributů života v prarodičovském věku.

Zejména mladší děti měly tendenci popisovat stář́ jako sérii ztrát/odchodů či negativních událostí směřujících ke smrti, jak tomu je na př́kladu popisu vlastní budoucnosti u dívky a chlapce ze 3 . tř́ídy:

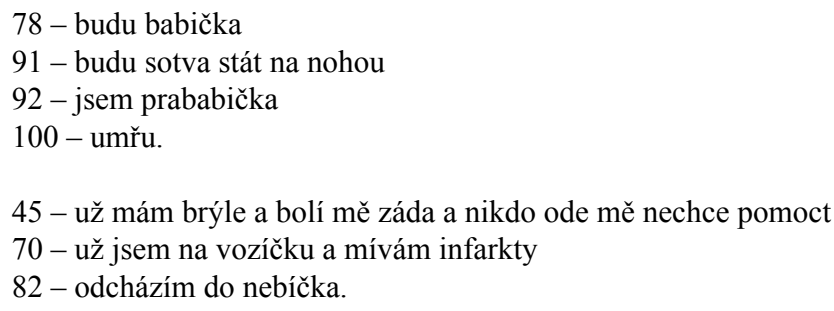

Dívka ze 7. třídy zmiňuje mezi životními událostmi také „krizi středního věku“:

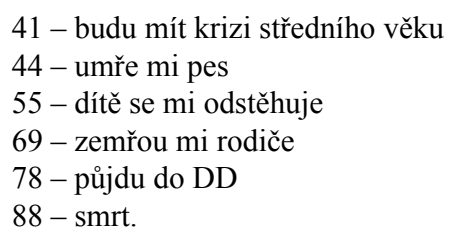

Starší děti vykresluji pestřejší obrázek života ve vy̌šším věku. Život v důchodovém věku je vnímaný jako klidný (,,poklidný život v domově důchodcư“, „,ůchod - klidné období“), naplněný realizací koníčkủ („,60 - postavím zahradní železnici“), časem tráveným s rodinou a př́jemnými aktivitami.

Popis posledních etap života se objevil také v některých písemných či obrazových ztvárněních představ o vlastní budoucnosti, které jsou podrobněji analyzovány $\mathrm{v}$ dalších částech 
textu. Tyto popisy a zobrazení vyššího věku jsou, a to u dívek i chlapců, spojeny s trávením času $\mathrm{v}$ prostředí rodiny:

V 65 si budu uživat života až do 75, čas budu trávit s rodinou a čtením a různými dobrými věcmi, v 90 umřu.

Dnes už je mi 70 a odcházím do důchodu. Mám 3 děti a zatím 4 vnoučata. Stále bydlím ve stejném domě se svojí manželkou. Naštěstí jsme oba zdraví, takže si můžeme užívat naspořených peněz a dědictví po rodičích. Dnes je mi 80. Jsem soběstačný, i když dost často nemocný. Dům jsem dal vnoučatům a bydlím u mé nejmladší dcery. Moje manželka už zesnula. [Na obrázku je nápisek se jménem autora, jeho datem narození a datem úmrtí 8. 11. 2089.]

Dvě starší dívky se ve svých vyprávěních vymezily proti představě o klidném stáŕí a zdůraznily, že chtějí být ve stář́i aktivní:

Až budou [děti, poznámka LS] z baráku, budeme si uživat volnosti, ale nikdy nechci zůstat jako stařečka se stařečkem kteří sedí v křesle. Chci si život užít co nejvíc.

V 50 letech budu mít hezká vnoučata a každodenní návštěvu u doktora. Budu bydlet v bytě nebo $\mathrm{v}$ chalupě na konci města. A o prázdninách ke mně budou vnoučata jezdit. Určitě budu čilá babka která bude jezdit na každoroční třídní srazy. Určitě pojedu taky do nějaké cizí země. Potom umřu a moje děti mě budou chodit zapalovat svičky na hřbitov.

Důraz na aktivitu či na užívání života ve vyšším věku je protipólem reprezentací stáríí, které se soustředily na ztráty a úbytek životních sil. Objevil se jen u starších dětí, u chlapců $\mathrm{v}$ podobě popisu komfortního a klidného života, u dívek v podobě důrazu na aktivity. Představa „,̌ilé babky“ jedné z účastnic našeho výzkumu je ukázkou jednoho z mnoha nároků na sebe samotnou, které na sebe, jak uvidíme dále, dívky kladou a který se v seniorském věku skutečně výrazně genderovaně promítá coby ideál aktivního stárí do životního stylu, jak ve svém výzkumu ukázala Jaroslava Hasmanová-Marhánková (2011).

Spektrum aktivit připisovaných staršímu věku se málokdy týká pracovní sféry či sféry partnerství - tři chlapci uvedli jako součást své představy o životě ve vyšším věku profesní úspěch (54 - jsem prezident, 70 - vstup do politiky, 76 - jsem světový miliardář), že bude v 60 letech pracovat, uvedla jen jedna dívka. Podobně partnerské změny nejsou něčím, co je ve vyšším věku očekáváno, s výjimkou ovdovění, které bylo zmíněno často - kromě něj se $\mathrm{v}$ časových osách jako událost objevil jeden rozchod a jeden rozvod, a jeden opakovaný sňatek (po ovdovění, v 69 letech).

Jedna ze starších dívek zmínila po ovdovění „zamilování a sex“, které připojila k věku 60 let, o rok později však následuje událost popsaná jako „onemocnění pohlavní chorobou“, která provokativně zdůrazňuje netypičnost takto zvolené životní dráhy a můžeme ji vnímat jako sankci za překročení věkových norem (po události „první sex“, kterou tato dívka zasadila do věku 15 let, žádné onemocnění nenásleduje) a normalizaci takové životní dráhy - sex ve vy̌ším věku není něčím, co by se očekávalo, choroby a onemocnění jsou naopak spojovány s vyšším věkem nejčastěji. 
Vlastní smrt umístily na časové ose téměř všechny děti - dva chlapci opatřili také své obrázky budoucnosti obrázkem pomníku s datem narození a úmrtí u vlastního jména. Smrt děti načasovaly do období od 77 let, obvykle se objevuje kolem stovky (často 90, 99 a velmi často přesně 100 let). Představa št’astné smrti je kromě vysokého věku, v němž byla smrt na časové ose umístěna, podpořena $\mathrm{v}$ několika prrípadech $\mathrm{i}$ zmíněním jejích konkrétních okolností - jako je úmrtí ve spánku či představou dalšího života po smrti, jako je „odcházím do nebička" a podobně:

V 60 letech budu mít 4 vnoučata a v 65 půjdu do důchodu a v 82 letech půjdu do domova důchodců a umřu v 85. A přijdu do nebe (podtrženo účastnicí výzkumu).

Smrt je něčím, co životní dráhu zobrazenou na časových osách v rámci našeho výzkumu pro většinu dětí uzavírá a čím se takto projektovaný život završuje - do časové osy ji umístila většina dětí, a to i těch, které neuvedly žádné události související s vyšším věkem.

Kromě výše uvedeného odchodu do nebe coby spirituálně laděného popisu smrti zmínili dva chlapci sci-fi scénáře budoucí smrti a nového života $-v$ jednom případě skrze zmrazení a užití nesmrtelného nápoje, ve druhém případě skrze reinkarnaci:

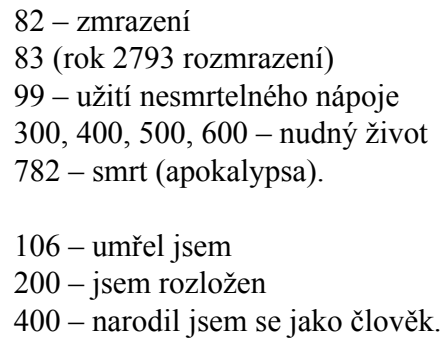

Smrt není pro děti tak cizím a vzdáleným tématem, jak si dospělí často myslí, děti o smrti přemýšlejí, vyvíjejí si vlastní perspektivu smrti či života po smrti a různým způsobem zpracovávají zkušenost se smrtí, která je jim zprostředkována at' už skrze zkušenost z vlastní rodiny a okolí nebo média a aktivity, jako jsou počítačové hry (Loučka a Vančura 2011).

Kromě úmrtí svého a úmrtí vlastních rodičů některé děti jako událost ve své životní dráze označily úmrtí domácího mazlíčka - událostí spojené se zviŕaty byly na časových osách zmiňovány často.

\section{Genderový rozměr představ o budoucnosti}

Děti jsme také požádaly, aby formou obrázků, případně obrázků s nějakým popisem (mladší děti) nebo formou psaného popisu či vyprávění ztvárnily své představy o budoucím životě. Ve zpracování tohoto úkolu jsme jim nedávaly žádné další instrukce, takže některé z nich jej pojaly jako slohovou práci, jiné jako obrázek s popisky či delším textovým komentářem, některé nakreslily obrázek bez popisků a komentáře. Takto volné zadání vedlo $\mathrm{k}$ různým 
pojetím úkolu - slovo „představa“ (v zadání použité jako „napište nebo nakreslete, jak si představujete svůj budoucí život"), které popis často uvozovalo, může evokovat jak očekávání toho, co se pravděpodobně stane, tak představu ve smyslu přání či snu, ale také představu ryze fantazijní, a všechny možnosti pojetí slova představa ze zadání se v pracích dětí objevily. V rámci cíle našeho výzkumu však různé uchopení úkolu není problém - nepracujeme s rozlišováním míry „realističnosti“ dětských představ či s jejich poměřováním, nepovažujeme ani současné představy za něco, $\mathrm{k}$ čehož naplnění bude budoucí život dítěte (at’ už vědomě či nevědomě) směřovat, ale sledujeme, jaké vzorce a pravidelnosti se v projekcích budoucího života projevují, jak odlišně či naopak podobně je tato budoucnost strukturována. Jak navíc ukazujeme v dalším textu, představy zakotvené ve fantazijním světě často vykazují podobné rysy jako představy, které bychom mohli vnímat jako realistická očekávání podoby vlastní budoucnosti. Představy jsou spíše projektováním současné situace a současného vnímání sociálního světa a jeho hodnot a vlastní pozice v něm do budoucího světa, a právě odraz tohoto vnímání v nich je nejvíce zajímavý.

Dětští aktéři se také umějí vǔči zadání úkolu vymezit, př́ípadně svou pozici ve vztahu $\mathrm{k}$ vlastní práci definovat. Tak např́íklad dvě dívky ze 7. třídy připojily ke slovnímu popisu vlastní budoucnosti, který vytvořily, dovětek o tom, že „sice to není moje představa ale je mi to jedno protože žádnou představu nemám“. Jiná, stejně stará dívka, se naopak označila za někoho, kdo „představu má“ („,Přesně nevím kde bych chtěla bydlet, ale nějakou představu mám“). Jiné děti používaly ve svých popisech slovo „možná“. Jedna ze starších dívek konfrontuje vlastní přání s realistickým očekáváním př́imo ve svém popisu:

Svůj život si představuji tak že budu mít dvě až tři děti, ideálně dva kluky a holčičku. Budu bydlet $\mathrm{v}$ domě s velkou zahradou, bazénem a hezkými plastovými okny. (No ale asi bych to viděla tak, že budu bydlet v malém bytě na okraji města.) [Závorka je původní, poznámka LS.]

Co se týče samotného obsahu sdělení, obrázky dívek a chlapců týkající se jejich budoucnosti, stejně jako jejich popisy nebo samostatná vyprávění o budoucnosti, se na první pohled př́iliš neliší. Tím, co je na nich zobrazeno nebo popisováno nejčastěji, jsou domy s bazénem, viŕivkou a saunou, auta či motorky a rodina sestávající z protějšku a dětí. Častým prvkem dětských popisů, obrázků a vyprávění jsou také zvíreceí mazlíčci. Děti popisují svou budoucnost $\mathrm{v}$ převážné většině jako budoucnost $\mathrm{v}$ konvenční rodině se dvěma rodiči opačného pohlaví a dětmi (nejčastěji dvěma) - jen pět popisů nebo obrázků z celkem 60 analyzovaných zmiňuje plán samostatného života bez rodiny, u devíti děti rodinu nezmiňují (tyto ne-rodinné plány se objevily jen u mladších dětí, u chlapců i dívek ve stejné míře), jejich popisy či obrázky se soustředí na pracovní sféru nebo volný čas.

Dívky i chlapci odevzdávali zhruba stejně rozpracované a bohaté obrázky, slovní vyjádření (popisy obrázků nebo samostatné slovní popisy) jsou u dívek delší než u chlapců a popisují mnoho detailů. Chlapci se častěji uchylovali k nadsázce (na obrázku namalované hromádky, popsané jako „hroudy zlata“) či schematickému nebo stylizovanému vyjádření (muž držící bankovky a vedle něj žena popsaná jako „mangelka“ atd.). Stylizace mužských postav (kšiltovka $\mathrm{s}$ jasně zřetelnou značkou, řetěz na krku) a časté zobrazování znaků bohatství (kromě peněz $\mathrm{v}$ podobě mincí a bankovek či zlata, konkrétně také v podobě aut či motorek 
věhlasných výrobců) na chlapeckých obrázcích odkazuje $\mathrm{k}$ raperským videoklipům, jimž právě tyto prvky dominují - pro obrázky dívek je těžké najít tak konkrétní předobraz v populární kultuře. ${ }^{6}$

Jedna ze starších dívek zasadila svou představu o budoucnosti do sféry sci-fi, i tam ale vykreslila obrázek rodiny složené z muže (bohatého) a ženy, jejich psů a dětí, včetně svatebního happy-endu, byt' následujícího po narození dětí a racionálně zdůvodněného. Jsou to tedy zejména kulisy a nikoli obsah, co tento text odlišuje od ostatních:

Nebudu se vdávat a budu žít $\mathrm{s}$ bohatým chlapem v bublině pod vodou. Velká vlna cunami nám zničí domovy a budeme žít pod vodou ve skleněných bublinách. Budu s ním mít 2 děti. 1 holku Annu nebo Kristýnu a 1 kluka Martina, Davida, Lukáše, Filipa, Tomáše. Bublina bude luxusní a 3 patrová. Taxíky nám budou dovážet pizzu zadarmo. Budeme jezdit v luxusních létajících limuzínách. Když budeme chtít jít na dno oceánu, nasadíme skafandry a za 20 let se lidé přizpůsobí životu ve vodě i bez něj. Hodně bych s prítelem cestovala na jiné planety. Budeme mít 2 psy (bígly) Charlieho a Maxe a 3 kočky Sáru a Matildu. Kanárka, kterého kočky později sežerou. Nakonec se budeme brát, kdyby se někomu z nás něco stalo, at' zdědíme peníze.

Rodinnou prosperitu a svůj vysněný život většina dětí popsala či zobrazila prostřednictvím materiálních symbolů či výčtu předmětů, které rodina vlastní. U některých, zejména starších dětí, lze naopak sledovat důraz na kvalitu života a odklon od aspirací na velký majetek (bydlení v „menším domku“ nebo „bytečku“; ekologické bydlení; farmaření; bydlení v hezkém prostředí; často v konkrétně definovaném prostředí, např́íklad ,jižní Morava“, „Olomouc“; štastný život; klidný život; aktivní život; užívání si života) a vztahů (trávení času s rodinou, vzájemná pomoc a dobré vztahy). Př́kladem je popis budoucnosti jednoho ze starších chlapců:

Moje rodina, ve které budu já, mé 2 děti, má žena, by bydlela na horské pláni ve srubu daleko od civilizace. Měl bych 2 psy a jednu bílou kočku. Já bych byl architektem a navrhoval bych nové ekologické sruby a chalupy, kterých by už kolem našeho srubu bylo dost. Pár set metrů pode mnou by u jezera bydlel můj nejlepší kámoš. Náš srub by byl sto metrů vedle řeky a pomocí lopatek bychom si sami vytváŕeli elektřinu.

$\mathrm{V}$ čem se dívky a chlapci výrazně odlišují, jsou jejich aspirace v rámci profesní a především soukromé sféry. Většina dětí zmínila své budoucí povolání. Mezi povoláními, které zmiňovali mladší chlapci, se objevují povolání s určitým hrdinským či elitním aspektem (kosmonaut, prezident, archeolog, policista ze speciální jednotky, fotbalista, tenista, kováŕ, návrhář hraček), starší chlapci zmiňují konkrétní povolání méně častěji, plánují budoucnost počítačového programátora či obecně někoho, kdo pracuje s počítačem, podnikatele (ten se spolu s počítačovým programátorem objevuje nejčastěji) či majitele různých firem, architekta. Mladší dívky zmiňují tato povolání: zpěvačka, pekařka, učitelka, lékárnice, veterinářka, právnička, návrháŕka oblečení, optik. Starší dívky pak uvedly povolání překladatelky a spisovatelky, designérky, klarinetistky, sekretářky, lékárnice, výtvarné umělkyně.

$6 \quad$ Za tento postřeh děkuji Petrovi Fučíkovi. 
Jednou z motivací pro volbu povolání je návaznost na povolání rodičů, kterou některé děti př́mo zmínily (,,chtěla bych chodit do práce jako optik. moje máma, táta, strejda a babička jsou nebo byly optiky“ nebo „chtěl bych pracovat v XY [jméno firmy prodávající nábytek] jako můj táta“). Jiné děti zmínily povolání v souvislosti se svými současnými koníčky a aktivitami, jakými jsou nejčastěji sport u chlapců (fotbalista, tenista) a umělecké činnosti u dívek. V tom, do jakých kroužků a volnočasových aktivit se děti zapojují, jsou patrné výrazné genderové rozdíly, které jsou opět v souladu s odlišným očekáváním od dívek a chlapců - dívky nad chlapci převažují v hudebně dramatických aktivitách, ve výtvarných aktivitách a ve vzdělávacích aktivitách, zatímco chlapci dominují ve sportovních a pohybových aktivitách a technických či turistických kroužcích (Bocan a kol. 2012).

Dívky také volily povolání, která jsou považovaná za typicky ženská (sekretáŕka, učitelka, lékárnice, designérka) a chlapci povolání, považovaná za mužská (programátor, policista, kovář). Všechny tři souvislosti volby povolání, které zde byly zmíněny (volba povolání na základě povolání rodičů, na základě současných volnočasových aktivit a na základě příklonu k povolání, v nichž dominují muži či ženy a která jsou tedy považována za adekvátní volbu pro chlapce a dívky) jsou př́kladem socializace dětí do genderově specifických životních drah. $\mathrm{V}$ jejich rámci se ženy ocitají na pracovním trhu na pozicích, které, ač kvalifikované, mají horší status a finanční hodnocení než pozice, v nichž dominují muži (blíže ke způsobům směrování dívek a chlapců do genderově specifických životních drah viz výzkum Jarkovské, Liškové a Šmídové [2010]).

Téma nízkého výdělku souvisejícího s některými povoláními není $\mathrm{v}$ projekcích budoucnosti př́mo zmíněno, dívky ale někdy anticipují svou horší pracovní pozici ve srovnání s partnery. Dívka ze 3. tř́ídy, která uvedla, že si přeje být pekařkou, zároveň popsala svého budoucího manžela jako bohatého a vzdělaného, skromnost svých profesních aspirací v kontrastu s očekáváním od partnera vyjádřila jedna ze starších dívek takto: „Manžel je úspěšný architekt a já už méně úspěšná sekretářka.“.

Genderované životní dráhy jsou projektovány i dále do budoucnosti, do představ o aktivitách vlastních potomků, pro které chlapci i dívky plánují specifické aktivity a koníčky, ale i zapojení se do práce $\mathrm{v}$ domácnosti. Budoucí děti budou podle očekávání nejčastěji „chytré“, budou mít „hodně kroužků a kamarádü“. Častým dělením volnočasových aktivit tak, jak se objevily v popisech budoucnosti, je tanec pro dcery a sport pro syny. Jeden chlapec ze 3. tř́dy přisoudil dceři i synům sportovního koníčka, nezmiňuje však sport jako jednotnou kategorii, ale odděluje dva typy aktivit, klučičí „sport“ a dívčí „,ělání gymnastiky“: „Moji kluci budou sportovat (fotbal, hokej...), dcera bude dělat gymnastiku.“. Uměleckou budoucnost pro všechny děti (své dcery i syna) plánuje jedna ze starších dívek. Jedna z dívek počitá se svými potomky také pro pomoc v domácnosti, jak ale uvádí, „podle toho co budou za pohlavi“".

Dívky si také zvolily (s výjimkou výše zmíněné pekařky či sekretářky) profese náročné na kvalifikaci nebo talent. Je zřejmé, že pro většinu dívek je úspěch v profesním životě podstatný a vnímají jej jako rovnocenný s úspěchem v osobním životě, nebot' oběma sférám věnují ve svých popisech budoucnosti významný prostor.

Chlapci nejčastěji zmiňují zejména profese navázané na předpoklad vysokého př́ijmu, jako je majitel firmy, podnikatel nebo programátor. Na časové ose jeden z mladších chlapců 
jako plán pro svůj věk 18 let uvedl „dostávám 30 tisíc měsíčně“, aniž by se zmínil o zdroji těchto př́ijmů. Dívky naopak svůj plat či výdělečnost profese netematizují, více prostoru ve srovnání s chlapci naopak věnují charakteristikám, profesi a bohatství svého partnera.

$\mathrm{Na}$ rozdíl od chlapců mají dívky detailnější představy o charakteristikách partnera (jméno, věk), stejně jako o jménech dětí nebo budoucích domácích mazličků. Chlapci se, co se týče manželky, obvykle spokojují s charakteristikou hodná a hezká (v jednom př́padě „nádherná“ a také „hraje tenis“), dívky očekávají od manžela specifické vlastnosti (někdy př́sný a někdy hodný; hodný a milý, ale i chytrý a vzdělaný; zodpovědný, milý, pracovitý) konkrétní vzhled (hnědovlasý, sympatický, černovlasý a hnědé oči), profesní úspěch (úspěšný architekt, vedoucí firmy) a bohatství (bohatý, středně bohatý, bude mít moc peněz). Zároveň některé vlastnosti vylučují: neměl by pít ani utrácet peníze, neměli bychom se hádat; podobně jeden z chlapců vyloučil tvrdohlavost u své manželky. Vlastnosti partnera tedy dívky zmiňují jako významnou součást své budoucnosti. Podle Jarkovské (2010) dívky důrazem na charakteristiky manžela (a jeho schopnost vydělávat peníze) vyjadřují svá očekávání toho, že svůj sociální status získají mj. také skrze partnerství.

O fyzické blízkosti svých původních rodin ve své dospělosti, případně o péči o rodiče a přaní zachovat do budoucna vztah a blízkost $\mathrm{k}$ dalším členům rodiny (např́íklad sourozencům) psaly tři dívky a žádný chlapec. Jedna z dívek na obrázku o své budoucnosti nakreslila sebe $\mathrm{v}$ práci a rodiče a jeden $\mathrm{z}$ mladších chlapců nakreslil jako svou představu o budoucím životě restaurační podnikání společné s jeho rodiči.

Děti se také (možná pod vlivem diskuse o rolích v rodině, která proběhla v předchozí návštěvě tř́íd jako focus group nad vinětami rodin s různě uspořádanými rolemi) někdy vyjadřují $\mathrm{k}$ dělbě práce $\mathrm{v}$ domácnosti - tu chlapci popisují jako tradiční (manželka na obrázku není, protože šla na nákup; manželka nebude pracovat, budu vydělávat sám; manželka vychovává děti, já jsem dlouho v práci). I když jeden z nich počítá s tím, že „manželka nebude vařit“, neznamená to, že bude vařit on, ale že ,jídlo budeme kupovat nebo od babiček“. Jeden z mladších chlapců zobrazil sebe samotného jako muže vracejícího se autem domů, který se zdraví a vítá se dvěma dětmi a ženou, každý z nich na něj přitom mává z jednoho okna klasického rodinného domu se sedlovou střechou a kouřícím komínem. Zobrazil tedy moderní rodinu s komplementárními rolemi otce a matky, v níž matka a děti zůstávají v prostoru domu a čekají na návrat muže z výkonu placeného zaměstnání.

Dívky se, co se týče dělby práce $\mathrm{v}$ domácnosti (a př́padných dilemat nebo konfliktů s tím spojených), vyslovují spíše pro tradiční uspořádání: „manžel se bude starat o mužské práce a já budu dělat ty ostatní věci“, ,já budu na mateřské“, „,manžel chodí z práce brzo, nosí si práci domů a tak ta dřina zůstane na mě“, ale některé z nich počítají s jinou dělbou prací. Jedna z dívek napsala, že si děti bude s manželem „půjčovat“, jiná, že dobře vydělávající manžel „bude mít čas i na rodinu“, př́ípadně se svým úspěšným angažmá v obou sférách: „Já budu ten, kdo se bude starat o domácnost, ale budu i pracovat (přes počítač) a budu vydělávat více peněz.“.

Představu o svém vkladu do rodinného života děti sdělovaly také prostřednictvím popisu svých budoucích koníčků a rodinných aktivit. Koníčky pro sebe, stejně jako povolání, vybírají chlapci ze sféry tradičně mužských zálib a prezentují je jako individuální: hrát fotbal, být na počítači, tuning, šachy, chození po horách. Chlapci se také zobrazují samostatně nebo 
s kamarádem či příbuzným na chatě nebo na chalupě, př́ípadně při různých aktivitách (pracovních i volnočasových), kdy rodina zobrazena není, i když je někdy zmíněna v popisu. Pokud se dívky zobrazily samostatně (tzn. bez dětí i bez partnera), zasadily svou postavu do prostoru práce. Koníček, který by provozovaly samostatně bez rodiny, dívky nezmínily, pokud se mezi ně nedají počítat umělecké aktivity (výtvarné umění, zpěv), které mohou být zároveň povoláním. Výjimkou je dívka ze 3 . tř́idy, která se přihlásila $\mathrm{k}$ tradičně mužské zálibě - fotbalu. Zároveň je dívkou, která ve svých plánech zmiňuje na předním místě „dobrou práci“ a prání vlastnit motorku, stereotypní očekávání tak narušuje hned v několika ohledech.

Já bych si přála, abych měla svůj dům, dobrou práci, mít 2 děti nebo 3 . mít tak akorát peníze. Můj manžel by měl být hodný, neměl by pít ani utrácet peníze a chtěla bych mít motorku. Já bych chtěla být veterinářkou a můj koníček je hrát fotbal.

Že si je výjimečnosti svého koníčku vědoma je zřejmé z následného rozhovoru s výzkumnicí, kdy fotbal okomentovala jako něco co „už nedělá“. V interakci s výzkumnicí tak naplnila očekávání od aktivit vhodných pro dívky, mezi které fotbal nepatř́i - v psané práci bylo nejspíše jednodušší, než v konfrontaci s dospělou osobou, tato očekávání narušit.

Co se týče cestování, které dívky i chlapci ve svých představách o budoucím životě zmiňují velmi často, dívky je na rozdíl od chlapců prezentují jako aktivitu rodinnou a používají téměř vždy množné číslo (,budeme cestovat“), případně píší, že budou cestovat „,s manželem a dětmi“, některé z nich se podrobně zabývají i dalšími rodinnými aktivitami, jako dvě dívky ze 7. trrídy v následujících dvou ukázkách, po nichž následuje ukázka z popisu chlapce ze stejné trí́dy:

[...] pěstujeme zeleninu ale vyskytne se tam i sem tam nějaké ovoce. [...] Také často chodíme na procházky do lesa nebo jen tak na hřiště. Sem tam zajdeme i do kina nebo nějakého obchodu. Někdy jdeme i s kamarádama na pivo. Každé léto jedeme dokonce i k moři, většinou do Řecka nebo Itálie.

Chtěla bych mít velký dům se zahradou, kde by byl bazén. Společně bychom se v něm koupali a chodili se opalovat. Kromě bazénu by byla na zahradě i bouda pro moje dva pejsky. Musí být malí, aby se s něma dalo dobře mazlit. Budeme mít dvě auta, protože budeme hodně cestovat.

Chtěl bych bydlet na kraji města. Budu mít alespoň dvě auta. Jedno bude na tuning. Druhý pro rodinu. U domu bude bazén. Budu mít psa.

Téměř žádný plán formulovaný v množném čísle u chlapců až na dvě výjimky nenajdeme. Na rozdíl od chlapců také dívky blíže popisují další společné aktivity s dětmi nebo své rodičovské ambice (,svým dětem se budu plně věnovat“, „Budu chtít být dobrá máma, takže budu jezdit s dětmi na výlety a věnovat se jim“, „,chci děti učit jazyky“, „budeme s dětmi a manželem sportovat“), případně blíže charakterizují vztahy a hodnoty v rodině („,budeme se mít rádi a pomáhat si“, „budeme věřící rodina“, ,je mi jedno jestli budeme bydlet ve vile nebo v bytě, v Česku nebo ve Francii, ale hlavně at’ jsme pohromadě a máme se rádi“). Tři dívky zmiňují také plány na charitativní činnost - pomoc „černouškưm“ v Africe a založení „útulku“ (společný plán dvou kamarádek). 
Za chlapeckou verzi těchto aktivit můžeme považovat některé př́iklady heroických životních drah, které byly popsány na časových osách - jeden z chlapců uvádí, že od narození do sto let chce „bojovat za spravedlnost“, ve čtyřiceti letech být Old Shatterhandem i Vinnetouem a také chytit „Kárli Bila“; jiný napsal, že ve sto letech získá ocenění hrdina lidstva za zabití syna Usáma bin Ládina, další z chlapců napsal, že bude „mít svaly a chytat zločince“, jiný očekává v 99 letech ocenění za „dlouhověkost“. Sebe v budoucnosti jeden z chlapců dále nakreslil jako člena speciální vojenské jednotky, který se na obrázku ocitá $\mathrm{v}$ přestřelce $\mathrm{s}$ jiným uniformovaným člověkem, zatímco jeho rodina, která na obrázku není vidět, se podle popisu připojeného k obrázku „schovává v domě“. Představy o aktivitách ve sférách dobročinnosti či záchrany světa jsou opět výrazně genderově stereotypní u dívek se spojují s pečovatelstvím, u chlapců s hrdinskými výkony a uplatněním fyzické síly (svaly, zbraň) a moci. Zatímco u chlapců se takové prèedstavy vyskytly jen v mladším věku (a následně jsou opouštěny ve prospěch realističtějších představ o programátorství či podnikatelství jako hlavní činnosti), dobročinné aktivity zmínily starší dívky.

Žádný z chlapců nepopisuje nebo nezobrazuje, co bude dělat jako otec, jaký by chtěl být ve vztahu ke svým dětem, jaké vztahy $\mathrm{v}$ rodině budou, jak bude děti vychovávat, co bude spolu s nimi dělat, chlapci nezmiňují také plány na péči o někoho nebo angažování se v dobročinné sfére. Chlapci tedy svůj volný čas (ostatně podobně jako práci) popisují jako maskulinně orientovaný a individualistický, nezávislý na ostatních, dívky svou pozornost více upírají na činnosti a plány související s domácností, výchovou dětí, časem tráveným společně $\mathrm{s}$ rodinou, prípadně pomocí. $\mathrm{V}$ podobě nároku na dobrý výkon role matky (který zahrnuje čas věnovaný dětem, výchovu a vzdělávání, zodpovědnost za vztahy v rodině) a na své aktivity směrem $\mathrm{k}$ dobročinnosti tak dívky formulují další očekávání od sebe samých: vedle předpokladu, že budou (často výhradně) pečovat o domácnost, budou vykonávat náročnou profesi, dosáhnou sňatku s mužem určitých kvalit a aktivní postoj $\mathrm{k}$ životu si zachovají do vysokého věku.

Jak ukazují i jiné výzkumy, dívky mají tendenci vznášet na sebe vysoké nároky a aspirovat na úspěch hned v několika sférách, stejně jako usilovat o jejich úspěšné kombinování (Jarkovská 2010, Smetáčková 2010). Jedním ze způsobů, jak se vyrovnat s obtížně kombinovatelnými nároky různých životních sfér je podle Hoschschild (1993) usilování o ideál supermatky, která všechny své závazky a očekávání úspěšně zvládá. Dívky ve srovnání s chlapci vykazují větší vzdělanostní aspirace (Šmídová 2008), do úvah o své budoucí profesi ale zároveň promítají předpoklad nutnosti kombinovat práci ve veřejné sféře s péčí o rodinu (MŠMT 2008). Také výzkum Bocana a kol. ukazuje, že dívky ve svých aspiracích zdůrazňují mnohem více než chlapci vzdělání ( $32 \%$ dívek oproti $19 \%$ chlapců) a úspěch v profesi $(23 \%$ dívek oproti $15 \%$ chlapců). Chlapci oproti dívkám naopak častěji zmínili úspěch ve sportu ( $20 \%$ chlapců a jen $2 \%$ dívek) a peníze a slávu (12\% chlapců a $8 \%$ dívek) jako to, čeho by chtěli v životě dosáhnout. Také školní systém definuje dívky jako cílevědomější a snaživější (na rozdíl od chlapců, kteří jsou vnímáni jako méně ukáznění a disciplinovaní, ale projevující větší talent a nadání, které se rozvíjejí s věkem, na rozdíl od intelektuálních schopností dívek, které brzy dosahují svého maxima) (Jarkovská, Lišková 2010). Realističtější a cílevědomější představy dívek o vlastní budoucnosti mohou být odrazem vědomí toho, že se ve vzdělávacím systému musí více snažit, aby dosáhly podobného profesního postavení a platu jako 
chlapci (Jarkovská, Šmídová a Lišková 2010), případně očekávání, že ze vzdělání vytěží více než chlapci, například prostřednictvím zlepšení přístupu ke „kvalitněǰš́m“ partnerům a kvalitnějšímu životu obecně (Šmídová 2008), chlapci si naopak s vědomím výhod, které hegemonní status na pracovním trhu a v životě obecně přináší, mohou dovolit nárokovat více statků bez spojitosti s výrazným úsilím a své životní dráhy strukturovat volněji a méně realisticky (Jarkovská 2010).

Pro chlapce je rodina určitým atributem, který ve svých popisech budoucnosti téměr̆ vždy zmiňují, avšak s ní související aktivity již neuvádí. Konvenuje to s chlapeckým přesvědčením, že jejich starostí je především vydělávat, zatímco o domácnost a děti se bude starat manželka. Podobně ale chlapci př́liš nepopisují své aktivity v práci, případně námahu spojenou s prací. Svou schopnost vydělávat ale demonstrují výčtem značek věcí, které vlastní, typické je to pro auta a motorky opatřené na obrázcích popisky nebo také popisem podnikatelské činnosti nebo zbohatnutí:

Vlastním Microsoft, Linux, Apple, Samsung, Nokia, Sonny Erikson, General Motors, Al Kaida, Škoda, Mercedes, Buggati, Porsche, Lamborghini, Ferrari, USA.

Po 10 letech si najdu lepší práci (podnikatel). Budu milionář a budu mít svoji vlastní firmu a vilu. Potom budu doma a firmu prodám za moc peněz, poté nebudu vydělávat. V 60 prodám vilu a koupím si přiměřený domek s bazénem.

Jeden z chlapců popisuje jinou, výjimečnou formu zbohatnutí - díky rodičům manželky.

Rodiče mé manželky (je jí třeba 29) jsou velmi bohatí a dům nám dali jako svatební dar.

Na rozdíl od chlapců dívky nezmiňují značky věcí a jejich očekávání ve vztahu k majetku jsou obvykle realističtější (podobně výzkum Jarkovské 2010). Své povolání také na rozdíl od chlapců nepopisují tak často ve spojení s vyděláváním peněz, peníze zmiňují jako něco, co zkrátka budou mít, nebo pro ně figurují ve spojení s penězi a bohatstvím manžela. Zdá se, že podobně jako chlapec v předchozí ukázce bohatnou sňatkem; v príípadě dívek je ale tento scénář mnohem častější.

Rodina bude mít vilu hned vedle, kterou jim postavím a vše budu platit, manžel bude mít moc peněz.

Bohatství se ve výpovědi dívek projevuje především velkým domem s bazénem, několika auty, saunou a viŕivkou, př́ípadně dovolenými u moře, komfortně vybaveným a „útulným“ nebo „moderně zařízeným“ domem. Nepočítají s vlastními koníčky, ani s investicemi do nich či nákupem věcí, které by byly spojeny s vlastními aktivitami (jako je třeba motorka $\mathrm{u}$ chlapců či „auto na tuning“). Materiální aspirace dívek se ani v jednom př́́padě netýkaly předmětů, tradičně spojovaných s ženami (šaty, boty, kabelky či kosmetika), ani jejich plánované aktivity $\mathrm{v}$ budoucím životě nesměřovaly $\mathrm{k}$ péči o zevnějšek, jak to $\mathrm{v}$ př́padě sportu pro udržení postavy popisuje ve svém výzkumu Smetáčková (2010). Peníze jsou př́tomny také v plánech dívek na charitativní činnost nebo zabezpečení rodičů - konkrétně se ale o jejich 
zdrojích nezmiňují. Tak jako chlapci počítají s tím, že chod rodiny obstará partnerka, dívky od partnera očekávají, že rodinu materiálně zabezpečí, svá povolání nedávají do souvislosti $\mathrm{s}$ př́ijmem. Movitost svého partnera ale spojují s úsilím v práci (nosí si práci domů, chodí domů pozdě večer).

Důraz na výrazné znaky materiálního blahobytu u chlapců můžeme interpretovat také jako odraz potřeby performovat dominantní maskulinitu, jejíž součástí je právě viditelné bohatství odrážející úspěch ve veřejné sfére. Tyto tendence jsou výrazné (a mnohokrát popsané) právě ve vztahu ke školnímu prostředí, které podporuje stereotypní chování a dominantní vzorce maskulinity i feminity (Paechter 2007; Foster, Kimmel a Skelton 2001). Zároveň je rodinný dům $\mathrm{s}$ bazénem a autem jednoduše zobrazitelným, srozumitelným a široce sdíleným způsobem vyjádření idylických rodinných vztahů a lásky, způsobem, jak znázornit rodinnou prosperitu i individuální úspěch a štěstí, jak to vidíme například v reklamách, a to nejen $\mathrm{v}$ těch na bankovní produkty související s bydlením.

\section{Závěr}

Výzkumy dětské perspektivy jsou vždy poznamenány otázkou, do jaké míry a jakými způsoby je možné něco jako dětskou perspektivu zachytit a do jaké míry děti v kontaktu s výzkumníky reprodukují spiše než svou perspektivu to, co považují za očekávané a správné chování (viz $\mathrm{v}$ tomto čísle text Lucie Jarkovské). O výzkumech ve školním prostředí to platí dvojnásob, protože škola je institucí, která vede děti $\mathrm{k}$ tomu, aby se chovaly správně vzhledem ke společenským očekáváním, a která osvojení dominantních společenských hodnot nejen zprostředkovává, ale také hodnotí (Mahon, Glendinning 1996). Skutečnost, že děti reagují ve specifických interakcích tak, jak považují za správné a očekávané, však můžeme považovat za součást toho, co se ve výzkumech dětí označuje za dětské aktérství. Způsob, jakými vnímaná očekávání a normy děti reprodukují, ukazuje na to, jakými způsoby pracují s různorodými socializačními vlivy a očekáváními ostatních. Jak například ukázal výzkum Pimlott-Wilson (2011), v případech, že rodiče (či jiní rodinní prríslušníci nebo blízké osoby) coby významní socializační činitelé nestrukturují své biografie v souladu s normativním očekáváním, děti kalkulují se zisky a náklady spojenými s volbou různých životních trajektorií, a zdůrazňují snahu určité, kulturně sankcionované vzorce jednání (např́íklad dlouhodobou nezaměstnanost, nestabilitu partnerských vztahů atd.) neopakovat. Takové děti pak konstruují svou „zvolenou životní dráhu“, která reflektuje možnosti, které jim jsou dostupné, a zahrnuje rodinný vliv, včetně př́kladů toho, jaké vzorce jednání jsou méně žádoucí (Pimlott-Wilson 2011).

Časové osy i volněji formulované životní plány dívek a chlapců v našem výzkumu odrážejí kulturně předepsanou a očekávanou biografii popisovanou jako sled životních etap, začínající príípravou na život ve vzdělávacím systému a pokračující nabýváním kompetencí spolu se zvyšujícím se věkem a vrcholící jejich ztrátou ve věku vyšším. Životní dráhy projektované dětmi kromě kulturního scénáře odrážejí jejich aktuální zkušenosti, jako je např́íklad význam a blízkost rodiny, v níž děti žijí (úmrtí rodičů zobrazené na časové ose či zmínky o fyzické blízkosti rodičů či péče o ně v projekcích budoucího života) nebo důležitou pozici zviŕecích mazličků v jejich životě, ale i konzum určitých typů médií či obdiv k určitým typům hrdinů (především u chlapců). 
Podobně jako starší či dospělí respondenti z řady jiných výzkumů vyslovují účastníci našeho výzkumu ideál života, jehož hlavní osou je trvalý partnerský vztah, sňatek a založení rodiny, nejčastěji dvoudětné (Možný, Pakosta a Přidalová 2008; Fialová a kol. 1998; Katrňák a kol. 2010; Rabušic a Hamanová 2010). Vnímají také - dívky silněji než chlapci - očekávání toho, že nejdůležitější životní tranzice se mají odehrát do věku 30 let, který je v naší kultuře vnímán jako klíčový v souvislosti s přechodem $\mathrm{k}$ dospělosti a především s partnerstvím a rodičovstvím (Vidovičová 2008). Sdílejí také stereotypní vidění stáří jako období poznamenaného především úbytkem fyzických a psychických sil a jako období, ve kterém se nedá očekávat mnoho pozitivních změn či úspěch ve veřejné sféře.

Výzkum ukázal, že děti vnímají odlišnost očekávání ve vztahu k genderu, o své budoucnosti uvažují primárně jako chlapci a dívky. Zatímco dívky popisují ve svých budoucích životních plánech intenzivní a úspěšné zapojení se do rodinného, stejně jako do profesního života, chlapci projektují svou budoucnost coby budoucnost solitérů uprostřed rodin, jejichž životní styl a aktivity nejsou rodinným životem a vztahy $\mathrm{k}$ ostatním př́liš determinovány. Chlapci plánovaný životní styl je tedy vysoce individualizovaný, dominuje mu realizace vlastních profesních i volnočasových představ a úspěch $\mathrm{v}$ těchto sférách, jakkoli se odehrává v kulisách rodin. Chlapci očekávají, že budou mít moc nad svým časem a širokou možnost (včetně finančních prostředků) pro realizaci svých zálib, a to paralelně s prosperujícím rodinným životem, do kterého investují téměř výhradně jen jako živitelé. Plány dívek jsou naopak silně navázány na okolí, na rodinu (a to včetně rodiny původní) a vztahy. Tyto výpovědi jsou opět odrazem toho, jak děti reprodukují očekávání na ně kladená jako na dívky a chlapce, a ukazují na stereotypní způsoby, jakými je maskulinita a feminita konstruována v prostředí školní tř́ídy (Paechter 2007; Foster, Kimmel a Skelton 2001). Jsou mj. i odrazem zkušenosti života $\mathrm{v}$ české rodině, která je poznamenaná výrazně tradiční dělbou práce, díky níž zůstává mužům výrazně větší prostor pro individuální aktivity než ženám (Bierzová, 2006), a zároveň př́ijmovou nerovností mužů a žen (Jarkovská, Lišková 2010).

\section{Literatura}

BECK, Ulrich. Riziková společnost na cestě k jiné moderně. Praha : Sociologické nakladatelství, 2004. ISBN 9788086429328.

BECK, Ulrich; GIDDENS, Anthony; SCOTT, Lash. Reflexive Modernization. Cambridge : Polity Press, 1994. ISBN 9780745612782.

BERG, Lars-Erik. Children's Stories of Parental Breakup. In JENSEN, An-Magritt, McKEE, Lorna. (eds.). Children and the Changing Family. Between Transformation and Negotiation. London : Routledge Falmer, 2003, s. 120-133. ISBN 0415277736.

BIERZOVÁ, Jana. Rozdělení domácích prací v rodinách s dětmi. Gender, rovné př́ležitosti, výzkum. 2006, roč. 7, č. 1, s. 19-26. ISSN 1213-0028.

BOCAN, Miroslav. Děti v ringu dnešního světa: hodnotové orientace dětí ve věku 6-15 let. Praha : Národní institut dětí a mládeže Ministerstva školství, mládeže a tělovýchovy, 2012. ISBN 978-80-87449-24-0.

BOHN, Annette, BERNTSEN, Dorthe. The Future Is Bright and Predictable: The Development of Prospective Life Stories Across Childhood and Adolescence. Developmental Psychology, 2012, č. Oct 1. ISSN 1939-0599. 
Lenka Slepičková: „Firma vydělává, děti se učí, žena je hodná a já jsem šfastný.“

COLEMAN, Marilyn., GANONG, Lawrence H., FINE, Mark. Reinvestigating Remarriage: Another Decade of Progress. Journal of Marriage and the Family, 2004, roč. 62, č. 4, s. 1288-1307. ISSN 0022-2445.

FIALOVÁ, Ludmila. Představy mladých lidí o manželství a rodičovství. Praha : Sociologické nakladatelství. 2000. ISBN 8085850877.

FOSTER, Victoria, KIMMEL, Michael, SKELTON, Christine. 'What About the Boys?' An Overview of the Debates. In MARTINO, Wayne., MEYENN, Bob. (eds.). What About the Boys?: Issues of Masculinity in Schools. Buckingham, Philadelphia : Open University Press. 2001, s. 1-23. ISBN 978-0-3352062-4-7.

GREENE, Sheila., HOGAN, Diane. Researching Children's Experience. Approaches and Methods. London : SAGE. 2005. ISBN 0761971033.

HASMANOVÁ MARHÁNKOVÁ, Jaroslava. Aktivita jako projekt: Etnografie volnočasových center pro seniory. 2011. Disertační práce. Masarykova univerzita, Brno.

HOSCHILD, Arlie. The Second Shift. New York : Penguin Books, 2003. ISBN 9780142002926.

HUNT, Stephen J. The Life Course: A Sociological Introduction. New York : Palgrave Macmillan. 2005. ISBN 1403914702.

JAMES, Allison. Childhood Identities. Edinburgh : Edinburgh University Press. 2004. ISBN 0748604561.

JARKOVSKÁ, Lucie, LIŠKOVÁ, Kateřina. Genderové aspekty českého školství. Sociologický časopis, 2008, roč. 44, č. 4, s. 683-701. ISSN 0038-0288.

JARKOVSKÁ, Lucie, LIŠKOVÁ, Kateřina, ŠMÍDOVÁ, Iva. S genderem na trh. Rozhodováni o dalšim vzdělání patnáctiletých. Praha, Brno : SLON. 2010. ISBN 9788074190308.

JARKOVSKÁ, Lucie. Genderová reprodukce v každodennosti školni tř́dy: Etnografický výzkum. Disertační práce, Masarykova univerzita, Brno, 2010.

KATRŇÁK, Tomáš a kol. Na prahu dospělosti: partnerství, sex a životni predstavy mladých v současné české společnosti. Praha, Brno : Dokořán; Masarykova univerzita, 2010. ISBN 9788073633523.

KVAPILOVÁ BARTOŠOVÁ, M. Rozhodování o mateřství v životním běhu žen po třicitce. 2012. Disertační práce, Masarykova Univerzita, Brno.

LOUČKA, Martin, VANČURA, Jan. Koncept smrti u dětí: komponenty a determinanty. Československá psychologie, 2011, č. 1, s. 38-48. ISSN 0009-062X.

MAHON, Ann, GLENDINNING, Caroline. Researching Children: Methods and Ethics. Children and Society, 1996, roč. 10, s. 145-154. ISSN 1099-0860.

MOXNES, Kari. Children Coping with Parental Divorce: What Helps, What Hurts? In JENSEN, A.-M., McKEE, L. (eds.) Children and the Changing Family. Between Transformation and Negotioation. London: Routledge Falmer, 2003, s. 90-104. ISBN 0415277736.

MOŽNÝ, Ivo, PAKOSTA, Petr,PŘIDALOVÁ, Marie. Declining Fertilityin Europe, and, What Parenthood Means to the Czechs. Brno : Masaryk University, Georgetown. 2008. ISBN 9788021045545.

MŠMT, 2008. Důvody nezájmu žáků o prrírodovědné a technické obory. Výzkumná zpráva.

PAECHTER, Carrie, F. Being Boys, Being Girls: Learning Masculinities and Femininities. Maidenhead : Open University Press. 2007. ISBN 9780335219759.

PIMLOTT-WILSON, Helena. The Role of Familial Habitus in Shaping Children's Views of Their Future Employment. Children's Geographies, 2011, roč. 9, č. 1, s. 111-118. ISSN 1473-3285.

RABUŠIC, Ladislav, HAMANOVÁ, Ludmila. Hodnoty a postoje v ČR 1991-2008: (pramenná publikace European Values Study). Brno : Masarykova univerzita, 2009. ISBN 9788021049529.

RABUŠIC, Ladislav. Kde ty všechny děti jsou? Praha : SLON. 2001. ISBN 80-86429-01-6.

RYCHTAŘ́KOVÁ, Jitka. Demographic Transition or Demographic Shick in Recent Population Development in the Czech Republic? Acta Universitartis Carolinae. Geographica, 2000, č. 1, s. 89-102. ISSN 0300-5402. 
SOCIÁLNÍ STUDIA 2/2012

SMETÁČKOVÁ, Irena. Běžný den v životě žen a mužů - představy dívek a chlapců o vlastní budoucnosti. Studia paedagogica, 2010, roč. 15, č. 1, s. 107-124. ISSN 1803-7437.

ŠMÍDOVÁ, Iva. Muži na okraji: systémové znevýhodnění mladých mužů bez maturity? Gender, rovné přiležitosti, výzkum, 2008, roč. 9, č. 2, s. 22-28. ISSN 1213-0028.

VIDOVIĆOVÁ, Lucie. Stárnutí, věk a diskriminace - nové souvislosti. Brno : Mezinárodní politologický ústav Masarykovy univerzity. 2008. ISBN 9788021046276.

\section{Autorka}

Lenka Slepičková pracuje v Ústavu populačních studií na Fakultě sociálních studií MU. Výzkumně se zabývá se především sociologií rodiny (konkrétně dětskou perspektivou týkající se rodinných a partnerských vztahů či situací nedobrovolně bezdětných), sociologií medicíny (novými reprodukčními technologiemi a medicínskou profesí).

Kontakt: Fakulta sociálních studií, Joštova 10, 60200 Brno, slepicko@fss.muni.cz 